\title{
Production of paper from rose wastes
}

\author{
Fatma Bekdaş $^{\mathrm{a}}$ (D), Mustafa Karaboyacı ${ }^{\mathbf{b}, *}$ (D)
}

\begin{abstract}
The main ingredient of paper production is cellulose fibers. Usually produced from wood fibers and annual plants. In this study it was investigated usability of waste rose pulps (Rosa Damascena Mill.) which have environmental risk in Isparta province as a source of cellulose for paper production. Oily rose flower grows only in Isparta and its vicinity and around 7000 tons of rose flowers are grown annually. After oil extraction, rose flowers lose their economic value and are left to rot as garbage. Rose pulp which is an herbal waste therefore contains cellulose. At the Scope of study, cellulose content of rose pulp was determined and paper pulp was obtained by applying soda- $\mathrm{NaBH}_{4}$ and chlorite methods. The obtained paper pulp was mixed with waste paper in different ratio and paper production was provided. Thus, rose wastes which evaluating as rubbish, was recycled and go into the production cycle.
\end{abstract}

Keywords: Rose waste, Soda method, Chlorite, Paper, Pulp

\section{Gül posasından kağıt üretimi}

\begin{abstract}
Özet: Kağıt üretiminin ana maddesi selüloz liflerdir. Genellikle ağaç lifleri ve yıllık bitkilerden üretilir. Bu çalışmada Isparta ilinde çevresel risk taşıyan atık gül posaları (Rosa Damascena Mill.) kağıt üretimi için selüloz kaynağı olarak kullanılabilirliği araştırılmıştır. Yağlık gül çiçeği sadece Isparta ve çevresinde yetişmekte olup yıllık yaklaşık 7000 ton civarında gül çiçeği yetiştirilmektedir. Yağı alındıktan sonra gül çiçekleri ekonomik değerini yitirmekte ve çöp olarak çürümeye terk edilmektedir. Bitkisel bir atık olan gül posaları dolayısıyla selüloz içermektedir. Çalışma kapsamında. gül posasının selüloz içeriği belirlenmiş ve soda-sodyum borhidrür ve klorit yöntemleri uygulanarak kağıt hamuru elde edilmiştir. Elde edilen kağıt hamurları farklı oranda atık kağıtlar ile karıştırılarak kağıt üretimi sağlanmıştır. Böylece çöp niteliğindeki gül posaları geri dönüştürülerek üretim döngüsü içine katılmıştır.
\end{abstract}

Anahtar kelimeler: Gül posası, Soda yöntemi, Klorit, kağıt, Kağıt hamuru

\section{Introduction}

Recycling can be defined as the wastes that have reevaluation possibility can be reintegration into the production process after various processes in order to prevent resource depletion and waste minimization. With the increasing environmental concerns and the realization that oil resources are limited, the production of polymer materials from renewable sources has been gaining momentum for the last two decades.

Paper is one of the most important necessities of humanity with its place in cultural and industrial field. In the paper industry, cellulose and wood pulp are produced from cellulose-containing plants and waste paper raw materials. These intermediates are then converted into paper by various mechanical and chemical processes. That is to say, the main raw material of paper production is cellulose, a natural polymer. Cellulose, which forms the basic structure of plants and trees, is the most abundant polymer in nature and has found many uses since it is a polymeric product other than the main uses such as paper and cardboard.

The main raw material of the paper and cardboard industry is wood. Annual paper consumption has reached
350 million tons in the world. While the paper and cardboard production in Europe was 51.0 million tons in 2000, it will be 83.7 million tons in 2020 and consumption will increase from 47.7 million tons to 79.8 million tons annually (Odabaş and Gümüşkaya, 2006). The increase in the use of wood and the decrease in forest resources in the forest products industry led the paper industry to different alternative raw materials. One of them is the use of annual plants and their wastes in pulp and paper production. In this context, many studies have been carried out and are continuing (Tutus et al., 2015).

Rapid increase in volume and types of solid and hazardous waste because of continuous economic growth, urbanization and industrialization, is becoming a burgeoning problem for national and local governments to ensure effective and sustainable management of waste. It is further estimated that between 2007 and 2011, global generation of municipal waste will rise by $37.3 \%$, equivalent to roughly $8 \%$ increase per year (Manual, 2009).

Isparta area, production of essential oils has major commercial importance. According to the Turkish Republic Ministry of Industry and Trade report in the year 2011, agricultural production of rose flowers in the Isparta area

\footnotetext{
$\llbracket$ a Qualchem Diş Tic. A.Ş. Atatürk Mahallesi, Gazi Cad., No: 18/1, Esenyurt/İstanbul

b Süleyman Demirel Üniversitesi, Mühendislik Fakültesi, Kimya Mühendisliği Bölümü, Isparta

@ * Corresponding author (İletişim yazar1): mustafakaraboyaci@ sdu.edu.tr

$\checkmark \quad$ Received (Geliş tarihi): 19.08.2019, Accepted (Kabul tarihi): 26.09.2019
}

Citation (Atıf): Bekdaş, F., Karaboyacı, M., 2019. Production of paper from rose wastes. Turkish Journal of Forestry, 20(3): 250-253. DOI: $\underline{10.18182 / \text { tjf.606686 }}$ 
yielded over 7000 tons per year. After extraction, the flowers lose their value and become waste. There are no ways to destroy these waste flowers. (Karaboyac1, 2014). Agricultural wastes are lignocellulosic materials containing three basic structural components as hemicellulose, cellulose and lignin. Besides these, they also contain some extractive components (Karaboyac1 et al., 2017). As an alternative to wood-based raw materials, annual plants and agricultural wastes are the most important raw material resources for pulp and paper production (Tutuş et al., 2015).

In this study, the use of lignocellulosic wastes from rose oil industry in paper production was investigated. Paper pulp was obtained from rose pulps by delignification with sodium chloride and soda method. The stratification properties of the obtained pulps were investigated.

\section{Material and methods}

\subsection{Chemical composition analysis of the rose wastes}

Waste rose pulp was subjected to chemical analyzes given below to illuminate its chemical composition. All analysis procedures are calculated by establishing a proportion on the basis of dry matter. The dried samples were ground and dried according to the TAPPI T $257 \mathrm{om}-85$ standard method. Drying was carried out at $103 \pm 2{ }^{\circ} \mathrm{C}$ in accordance with the standard. Waste rose pulp was subjected to chemical analyzes given below to illuminate its chemical composition.

Cellulose content: Kurschner and Hoffer 1969

Holocellulose content: Wise 1962

Alpha cellulose content: TAPPI T203 os-712

Lignin content: TAPPI T222 om-88

Ash content: TAPPI T211 om-85

Extractives: ASTM D1107-96

\subsection{Pulp production with $\mathrm{NaClO}_{2}$}

A method similar to Wise's method was used in the preparation of pulp by $\mathrm{NaClO}_{2}$ (Sigma \%100) delignification. Alcohol extracted $50 \mathrm{~g}$ of air dried rose pulp was refluxed with $600 \mathrm{ml}$ of purified water, $15 \mathrm{~g}$ of sodium chlorite $\left(\mathrm{NaClO}_{2}\right)$ and $5 \mathrm{ml}$ of glacial acetic acid $\left(\mathrm{C}_{2} \mathrm{H}_{4} \mathrm{O}_{2}\right)$ at $80^{\circ} \mathrm{C}$ for 1 hour at $100 \mathrm{rpm}$. At the end of each hour, $15 \mathrm{~g}$ of sodium chloride and $5 \mathrm{ml}$ of glacial acetic acid were added again, which was repeated three times. The resulting pulp was washed with acetone dilute $\mathrm{NaOH}$ and purified water.

\subsection{Pulp production by soda-sodium borohydride method}

Experiments were carried out in the production of pulp according to the soda method with a ratio of $15 \% \mathrm{NaOH}$, $0.5 \%$ sodium borohydride, 2 hours and liquor ratio is 5 to 1 (water:pulp).

\subsection{Paper production from pulp}

Pulp obtained from rose waste was gradually beaten in Hollander Beater up to $50 \pm 5 \mathrm{SR}$ degree. The moisture content of the beaten pulp was determined and Test papers were produced with in semi-automatic Regmed RK-21 Sheet former in a weight range of $70-75 \mathrm{gr} / \mathrm{m}^{2}$. Three replicate test papers were produced on Rapid Köthen paper machine according to ISO 5269/2 standard at $70\left(\mathrm{~g} / \mathrm{m}^{2}\right)$ weight from each mixing ratio. Physical properties of the papers such as breaking, the breaking length test (TAPPI T494 om-11) and burst index test (TAPPI T403 om-15) were performed according to relevant standards. Its optical properties were determined according to the standards of brightness (ISO 2469: 2014), whiteness (ISO 2469: 2014), yellowness (ASTM E313) and opacity (TAPPI T519 om02).

\section{Results and discussion}

Table 1 shows the chemical contents of rose pulp and various plants obtained by other researchers. As seen from the table rose wastes includes \%36 cellulose and high enough to be used in pulp production.

Table 1. Chemical composition of rose waste and other annual plant and wood species

\begin{tabular}{|c|c|c|c|c|c|c|c|c|c|c|}
\hline \multirow[b]{2}{*}{$\begin{array}{l}\text { Annual plant and wood } \\
\text { species }\end{array}$} & \multicolumn{6}{|c|}{ Chemical components } & \multicolumn{3}{|c|}{ Solubility } & \multirow[b]{2}{*}{ References } \\
\hline & $\begin{array}{l}0 \\
0 \\
0 \\
0 \\
0 \\
\vdots \\
0 \\
0 \\
0 \\
0 \\
0\end{array}$ & 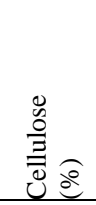 & 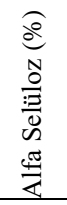 &.$\sqrt[5]{7} \overparen{8}$ & 至 & 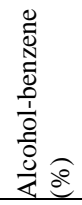 & 要 & 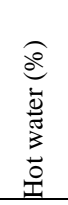 & $\begin{array}{l}\hat{0} \\
\frac{0}{0} \\
\frac{\pi}{3} \\
\frac{0}{0} \\
0 \\
0\end{array}$ & \\
\hline Rose waste & 65 & 36 & - & 20 & 5 & 10 & - & - & - & Identified \\
\hline Cocklebur & 80.9 & 49.4 & 40.9 & 21.1 & 2.3 & 0.74 & 23.2 & 4.5 & 3.7 & Özdemir et al., 2018 \\
\hline Astragalus & 76.7 & 36.7 & 38.2 & 23.6 & 5.5 & & 29.4 & 8.5 & 7.2 & Tutuş et al., 2014 \\
\hline Poppy Stalk & 79.8 & 40.9 & 51.7 & 19.2 & 4.7 & - & 30.4 & 10.4 & 5.1 & Tutuş et al., 2011 \\
\hline Cotton Stalk & 75.6 & 45.5 & 39.8 & 18.2 & 2.5 & 6.1 & 30.9 & 14.3 & 11.65 & Ezici, 2010 \\
\hline Cotton Stalk & 72.2 & - & 41.6 & 19.3 & 2.4 & 6.1 & 42.9 & 17.8 & 16.7 & Akgül, 2007 \\
\hline Wheat stalk & 77.1 & 52.3 & 39.6 & 18.3 & 7.1 & 5.5 & 40.9 & 12.3 & 7.65 & Tutuş, 2003 \\
\hline Rye stalk & 74.1 & 51.5 & 44.4 & 15.4 & 3.2 & 9.2 & 39.2 & 13.0 & 10.2 & Usta and Eroğlu, 1987 \\
\hline Corn stalk & 64.8 & 45.6 & 35.6 & 17.4 & 7.5 & 9.5 & 47.1 & 14.8 & - & Eroğlu et al., 1992 \\
\hline Tobacco Stalk & 67.6 & - & 37.5 & 19.5 & 7.3 & 6.5 & 42.9 & 19.1 & 15.8 & Tank et al., 1985 \\
\hline Cane & 77.9 & 50.3 & 47.5 & 18.7 & 3.9 & 4.0 & 28.3 & 3.8 & 3.30 & Kurc1, 1996 \\
\hline Kenaf & 81.2 & 54.4 & 37.4 & 14.5 & 4.1 & 5.0 & 34.9 & 12.8 & 11.7 & Doğan, 1994 \\
\hline Coniferous Trees & $63-74$ & $55-61$ & - & $25-32$ & $0.2-0.5$ & $1-5.8$ & $8-10$ & $1-5$ & $0.5-4$ & Kırc1, 2006 \\
\hline Leafy Trees & $72-82$ & $38-55$ & - & $18-26$ & $0.2-0.7$ & $1-6.2$ & $12-25$ & $1-8$ & $0.2-4$ & Kurc1, 2006 \\
\hline
\end{tabular}


Figure 1 indicates that the pulp obtained from rose wastes with sodium chlorite method. The pulp obtained with $\mathrm{NaClO}_{2}$ has the desired degree of whiteness. However, the intense chemical effect that expose to rose pulp during bleaching caused degradation of cellulose fibers. Therefore, drainage problems were experienced during paper production and no stratification was observed.

Figure 2 shows the paper produced from $100 \%$ rose pulp obtained with soda method. As seen from the picture pure rose pulp is not suitable for paper production. Because of the problem of filtration and drainage during the production of paper from $100 \%$ waste, smooth layers could not be obtained. Therefore, pulp obtained from rose pulp was mixed with waste paper in different ratios and paper production was tried.

In Figure 3, papers are seen obtained by mixing rose pulps with different amount of waste paper pulp. When a proper paper could not obtain from $100 \%$ waste rose pulp, then rose pulp was mixed with 50-60-70-80-90\% waste paper pulp and new papers were produced. The mechanical and optical test results of the papers are shown in Table 2 .

When Table 2 was examined, it was found that the breaking length and burst index values of the papers are increased by the addition of rose pulp. The best breaking length value was obtained from the addition of $20 \%$ and $30 \%$ rose waste pulp, while the highest burst index value was obtained with $50 \%$ rose waste pulp. According to Table 2 , the optical properties of the paper were negatively affected by the addition of rose pulp.

It is considered that $30 \%$ rose pulp and $70 \%$ waste paper pulp blend is more suitable if economic, physical and optical properties are taken into consideration in the evaluation of rose waste in pulp and paper production. Compared to the paper produced from this blend control example, ie, $100 \%$ waste pulp, the breaking length and burst index increased by $37.9 \%$ and $32.6 \%$, respectively. Whiteness and brightness values decreased by $5.93 \%$ and $12.8 \%$, respectively. These reductions in optical properties can be prevented by single-stage bleaching of pulp obtained from rose wastes.

Tutuş et al. (2015) produced papers by mixing tea wastes pulps with Turkish pine pulps. These researchers have similar results like this study. According to their results, burst index is $2.92 \mathrm{kPa} \mathrm{m}^{2} / \mathrm{g}$ and breaking length is $4.52 \mathrm{~km}$ in the mixture of $\% 50$ tea waste $\% 50$ pine pulp. In this study, burst index is $2 \mathrm{kPa} \mathrm{m} / \mathrm{g}$ and breaking length is $3.44 \mathrm{~km}$. Idarraga et al. (1999) performed a study about pulp and paper from blue agave waste from tequila production. They used conventional and two organosolv systems to pulp the agave waste. Their best burst index is $1.47 \mathrm{kPa} \mathrm{m}^{2} / \mathrm{g}$. Given these results, we can say that the rose industry wastes can be used in paper production.

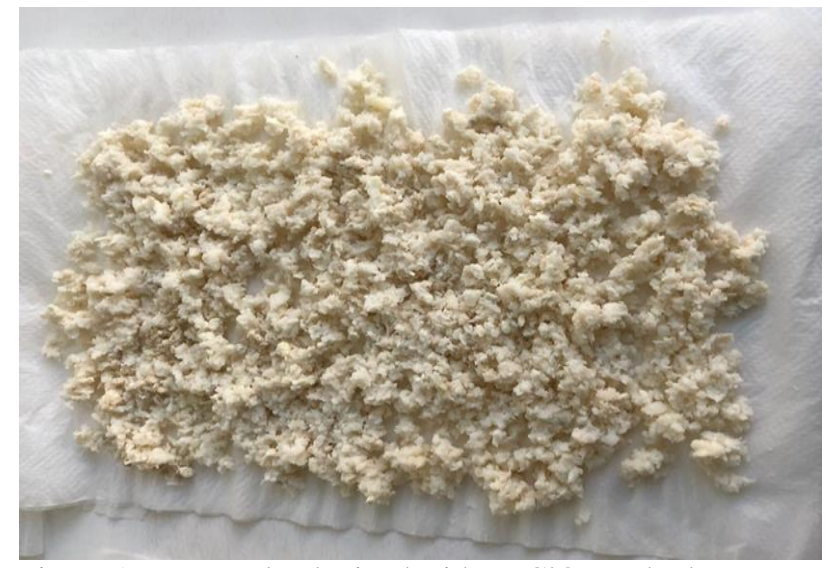

Figure 1. Paper pulp obtained with $\mathrm{NaClO}_{2}$ method

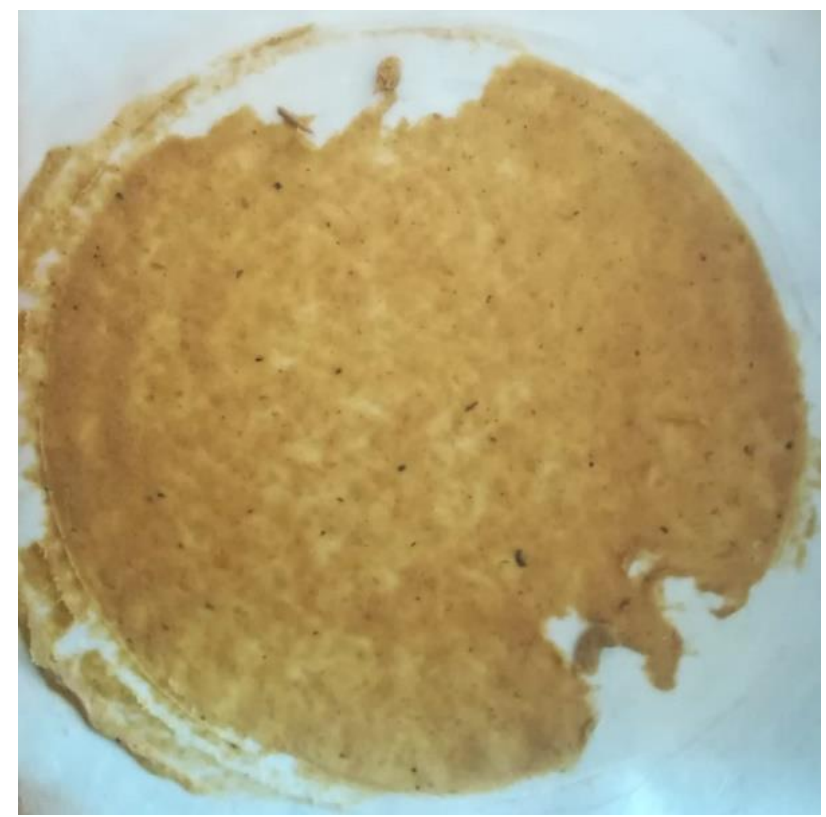

Figure 2. Paper obtained from 100\% rose pulp

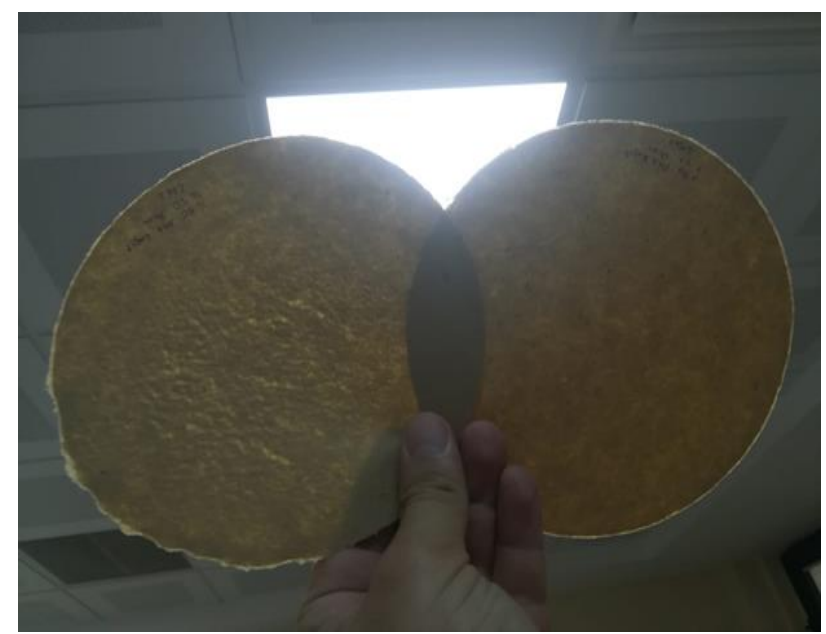

Figure 3. Paper obtained from 50\% rose pulp 50\% waste paper on left. Paper obtained from $30 \%$ rose pulp $70 \%$ waste paper on right 
Table 2. Physical and optical properties of papers obtained from rose pulp and waste paper pulp

\begin{tabular}{|c|c|c|c|c|c|c|c|c|}
\hline & $\begin{array}{c}\text { Waste paper } \\
(\%)\end{array}$ & $\begin{array}{c}\text { Rose pulp } \\
(\%)\end{array}$ & $\begin{array}{c}\text { Breaking } \\
\text { Length }(\mathrm{m})\end{array}$ & $\begin{array}{c}\text { Burst Index } \\
\left(\mathrm{kPa} \cdot \mathrm{m}^{2} / \mathrm{g}\right)\end{array}$ & $\begin{array}{l}\text { Whiteness } \\
\text { (ISO) }\end{array}$ & $\begin{array}{l}\text { Brightness } \\
\text { (ISO) }\end{array}$ & $\begin{array}{l}\text { Yellowness } \\
\text { (E313) }\end{array}$ & $\begin{array}{l}\text { Opacity } \\
\text { (ISO) }\end{array}$ \\
\hline 1 & 100 & 0 & 2495 & 1.44 & 34.53 & 24.44 & 43.51 & 99.52 \\
\hline 2 & 90 & 10 & 3288 & 1.79 & 34.85 & 24.25 & 44.83 & 99.46 \\
\hline 3 & 80 & 20 & 3449 & 1.78 & 33.96 & 23.13 & 46.59 & 99.61 \\
\hline 4 & 70 & 30 & 3440 & 1.91 & 32.48 & 21.30 & 50.00 & 99.36 \\
\hline 5 & 60 & 40 & 3241 & 1.97 & 31.54 & 20.16 & 52.17 & 98.98 \\
\hline 6 & 50 & 50 & 2953 & 2.00 & 29.74 & 18.35 & 55.22 & 98.13 \\
\hline
\end{tabular}

\section{Conclusion}

In this study, in order to investigate the usability of rose wastes in paper production, pulp was produced from waste rose flowers by only two methods. Chlorite method yielded sufficient whiteness of pulp, but due to its intense chemical effect, cellulose fibers were hydrolyzed by degradation. Although pulp was obtained in the soda process, however, paper formation could not be obtained due to drainage problem from pure rose pulp. It can be said here that sodium hydroxide, used at a rate of $15 \%$, damages the cellulose fibers in fine rose flowers. The study showed that rose pulp can be used in paper production. However the processes that we use must be optimized to avoid damaging the fibers.

\section{Acknowledgment}

We would like to thank TÜBİTAK, 2209-B IndustryOriented Undergraduate Graduation Thesis Support Program for supporting the realization of the study.

\section{References}

Akgül, M., 2007. Pamuk (Gossypium hirsutum L.) Saplarından Soda-Alkol, Soda-AQ, Soda-Alkol-AQ Yöntemleriyle Kağıt Hamuru Ve Kağıt Üretim Koşullarının Belirlenmesi. Düzce Üniversitesi, Bilimsel Araştırma Projeleri Başkanlığı, BAP Proje Kod No: 2005.05.03.221, Düzce.

ASTM D1107-96, 1998. Standard test method for ethanol-toluene solubility of wood. ASTM International, West Conshohocken, PA.

ASTM E313 2015. Standard Practice for Calculating Yellowness and Whiteness Indices from Instrumentally Measured Color Coordinates, ASTM International (ASTM).

Eroğlu, H., Usta, M., Kırc1, H., 1992. A Review of Oxygen Pulping Conditions of SomeNon-Wood Plant Growing in Turkey, Tappi Pulping Conference, 215-22.

Ezici, A.C., 2010. Pamuk saplarından (Gossypium hirsutum L.) Kraft -NaBH4 yöntemiyle kağıt hamuru ve kağıt üretim koşullarının belirlenmesi. K.Maraş Sütçü İmam Üniversitesi, Yüksek Lisans Tezi, Kahramanmaraş.

Idarraga, G., Ramos, J., Zuñiga, V., Sahin, T., Young, R.A., 1999. Pulp and paper from blue agave waste from tequila production. Journal of agricultural and food chemistry, 47(10): 4450-4455

ISO 2469: 2014. "Paper board and pulps. Measurement of diffuse radiance factor (diffuse reflectance factor)" International Organization for Standardization, Geneva, Switzerland.
ISO 5269-2, 2004. Pulp - Preparation of laboratory sheets for physical testing, Part 2:Rapid Köthen method. International Organization for Standardization, Geneva, Switzerland.

Karaboyacı, M., Tama, B., Şencan, A., Kılıç, M., 2017 Recycling of rose wastes to activated carbon with ecological precursor. Bilge International Journal of Science and Technology Research, 1(1):1-8.

Karaboyac1, M., 2014. Recycling of rose wastes for use in natural plant dye and industrial applications. The Journal of The Textile Institute, 105(11):1160-1166.

Kırcı, H., 1996. Soda-Oksijen Yöntemiyle Göl Kamışından (Phragmites communis L.) Kağıt Hamuru Üretim Koșullarının Belirlenmesi, KTÜ Araştırma Fonu, No: 95.113.002.6, Trabzon.

Kırcı, H., 2006. Kağı̆t Hamuru Endüstrisi Ders Notları. KTÜ Orman Fakültesi Yayınları, Yayın No:86, Trabzon.

Manual, T. 2009. Developing integrated solid Waste Management Plan. Prepared by United Nations Environ Program volume 3. UNEP Osaka/Shiga, Japan

Odabaş Serin, Z., Gümüşkaya, E. 2006. Kağıt ve karton endüstrisinde odun dışı lignoselülozik liflerin kullanımı. I. Uluslararası Odun Dışı Orman Ürünleri Sempozyumu, 1-4 Kasım, Trabzon/Türkiye, s. 645-654.

Özdemir, A., Tutuş, A., Çiçekler, M., 2018. Pıtrak (Xanthium strumarium L.) bitkisinin kağıt hamuru ve kağıt endüstrisinde kullanılabilirliği. Uluslararası Artvin Sempozyumu, pp: 949961, 18-20 Ekim, Artvin/Turkey.

TAPPI test methods, 1998-1999. Technical Association of the Pulp and Paper Industry. Atlanta, Ga. TAPPI Press, 1998.

Tank, T., Bostanc1, Ş., Eroğlu, H., Enercan, S., 1985. Tütün saplarının kağıt yapımında değerlendirilmesi. Doğa Bilimleri Dergisi, D2(9):3-9....

Tutuş, A., Eroğlu, H., 2003. A practical solution to silica problem in straw pulping. APPITA Journal, 56(2): 111-115.

Tutuş, A., Çiçekler, M., Karataş, B., 2011. Pulp and paper production by kraft-sodium borohydride method from poppy stems. II. International Non-Wood Forest Products Symposium, pp.183-190, 8-10 September, Isparta/Turkey.

Tutuş, A., Çiçekler, M., Özdemir, A., Altaş, A., 2014. Geven otunun (Astragalus Membranaceus) kağıt hamuru ve kağıt üretiminde değerlendirilmesi. III. Uluslararası Odun Dışı Orman Ürünleri Sempozyumu, 8-10 Mayıs, Kahramanmaraş.

Tutus, A., Kazaskeroglu, Y., Cicekler, M., 2015. Evaluation of tea wastes in usage pulp and paper production. Bioresources, 10(3): 5407-5416.

Usta, M., Eroğlu, H., 1987. Soda-Oxygen pulping of rye straw. Nonwood Plant Fiber Pulping Conference, November, Tappi Press, Progress Report, No. 18, pp.113-118, Washington.

Wise, E.L., Karl, H.L., 1962. Cellulose and Hemicelluloses in Pulp and Paper Science and Technology. Vol. 1. Pulp. Earl. C.L. (Ed.). McGraw Hill-Book Co.. Newyork. 